\title{
Pengembangan Buku Ajar Konsep Dasar IPA Sekolah Dasar untuk Meningkatkan Pemahaman Konsep Mahasiswa
}

\author{
Lefudin $^{1 *}$, Lukman Hakim ${ }^{2}$ \\ $1^{\star *}, 2$ Program studi Pendidikan Fisika, Universitas PGRI Palembang \\ Jl. Jend. A. Yani, Lrg. Gotong Royong 9/10 Ulu Palembang \\ *E-mail: lefudinle@yahoo.co.id
}

\begin{abstract}
Abstrak
Penelitian ini bertujuan mengembangkan buku ajar Konsep Dasar IPA SD untuk mahasiswa Program Studi Pendidikan Guru Sekolah Dasar (PGSD) Universitas PGRI Palembang. Metode penelitian yang digunakan adalah metode pengembangan modifikasi model pengembangan ADDIE dan model pengembangan Tessmer Penelitian ini terdiri dari empat tahap yaitu: tahap analisis, tahap desain, tahap pengembangan, tahap implementasi, dan tahap evaluasi. Kegiatan pada tahap analisis kebutuhan meliputi analisis materi, analisis buku-buku teks Konsep Dasar IPA SD dan karakteristik mahasiswa PGSD. Berdasarkan hasil analisis kebutuhan didesain buku ajar dengan materi konsep dasar IPA sesuai dengan karakteristik mahasiswa PGSD. Desain buku ajar menjadi prototype buku ajar konsep IPA. Berdasarkan prototype buku ajar yang dihasilkan dikembangkan buku ajar konsep IPA SD. Hasil pengembangan buku ajar dinilai oleh ahli dan diujicobakan. Hasil ujicoba menunjukkan bahwa $\mathrm{N}$-gain pemahaman konsep mahasiswa adalah 0,72 dengan kategori tinggi. Dengan demikian dapat disimpulkan bahwa buku ajar Konsep IPA SD dapat meningkatkan pemahaman konsep Fisika Siswa.
\end{abstract}

Kata kunci: Buku Ajar, Konsep Dasar IPA, Pemahaman Konsep

\begin{abstract}
This research aims to develop a textbook basic concepts of Elementary Natural Sciences for students of Primary Teacher Education Study Program, PGRI University of Palembang. The research methods used are ADDIE modification model and Tessmer development model. The research consists of five phases: analysis, design, development, implementation, and evaluation stage. Activities at the stage of need analysis include material analysis, analysis of basic concept of Elementary Natural Sciences textbook and the characteristics of Primary Teacher Education' students. Based on the results of the need analysis, a textbook was designed with basic science concept materials in accordance with the characteristics of Primary Teacher Education' students. The design of the textbook becomes a prototype of the science concept textbook. Based on the prototype of the produced textbooks, the textbooks for elementary school science concepts were developed. The results of the development of the textbooks are judged by the experts and tested. The test results show that $N$-gains understanding of the student concept is 0.72 with high category. Thus, it can be concluded that the textbooks of Elementary Science concepts can improve students' understanding of Physics concepts.
\end{abstract}

Keywords: Textbook, Science Concept, Understanding Concept

\begin{tabular}{|c|c|c|}
\hline Article History: & $\begin{array}{l}\text { Received: } 19 \text { Desember } 2019 \\
\text { Accepted: } 20 \text { Januari } 2020\end{array}$ & $\begin{array}{l}\text { Revised : } 27 \text { Jan } \\
\text { Published: } 31 \mathrm{Ja}\end{array}$ \\
\hline
\end{tabular}

How to cite: Lefudin, \& Hakim, L. (2020). Pengembangan Buku Ajar Konsep Dasar IPA Sekolah Dasar Untuk Meningkatkan Pemahaman Konsep Mahasiswa, 1(1). pp. 1-10. Retrieved from http://jurnal.fkip.unmul.ac.id/index.php/jpfp/index

Copyright (C) Januari 2020, Jurnal Literasi Pendidikan Fisika 
Pengembangan Buku Ajar...

\section{PENDAHULUAN}

Belajar merupakan sebuah konstruksi pengetahuan. Pikiran belajar seseorang dibangun berdasarkan skemata-skemata yang sudah ada pada dirinya yang dihubungkan dengan pengalaman sebagai penguatan (konstruksi pengetahuan) (Lefudin, 2018). Pengetahuan dikonstruksi peserta didik dengan mengatur pengalaman yang terdiri atas skemata-skemata yang sudah ada padanya (Suastra, 2004).

Ketika mengonstruksi pengetahuan, peserta didik sering dihadapkan pada faktor yang mempengaruhi pemahaman terhadap isi buku ajar yang digunakan. Untuk meningkatkan pemahaman konsep konsep siswa maka materi buku ajar disajikan dengan menggunakan multirepresentasi. (Doyan, Taufik, \& Anjani, 2018; Setyandaru, Wahyuni, \& Pramudya, 2017; Suhandi \& Wibowo, 2012). Dengan menggunakan multirepresentasi buku ajar ditampilkan dengan menggunakan teks, gambar, grafik atau persamaan matematika yang satu sama lain saling melengkapi untuk membantu siswa memahami isi buku ajar.

Penerapan multirepresentasi juga dapat meningkatkan motivasi belajar siswa (Doyan, Taufik, \& Anjani 2018). Dengan menggunakan multirepresentasi memberikan kesempatan pada peserta didik untuk belajar sesuai dengan gaya belajar yang paling disenangi sehingga hasil belajar yang diperoleh akan lebih baik.

Penggunaan multirepresentasi dalam buku ajar dapat membantu peserta didik dengan tingkat pengetahuan yang beragam. Peserta didik dengan tingkat pengetahuan yang lebih tinggi cenderung lebih senang belajar dengan menggunakan bahasa simbolik dan penerapan matematika. Kadangkala penjelasan secara verbal yang terlalu detil membuat peserta didik bosan. Sebaliknya peserta didik dengan tingkat pengetahuan yang lebih rendah cenderung lebih senang dengan penjelasan yang sangat detil disertai gambar ilustrasi fenomena yang sedang dibahas. Dengan demikian penerapan multirepresentasi pada buku ajar dapat membantu peserta didik memahami konsep walaupun peserta didik memiliki kemampuan yang berbeda.
Penerapan multirepresentasi dalam menyajikan materi konsep IPA dapat melatih siswa memahami konsep IPA lebih baik. Dengan menggunakan multirepresentasi peserta didik dilatih dan disuguhkan dengan konsep-konsep dalam format yang berbeda. Kemampuan peserta didik mengubah dari satu representasi menjadi representasi yang lain menunjukkan bahwa peserta didik telah memahami konsep. Pemahaman konsep merupakan kemampuan penting yang harus dilatih pada peserta didik untuk menghadapi kehidupan yang real di masa akan datang.

Dalam satu kelompok belajar atau satu kelas mahasiswa atau peserta didik memiliki kemampuan dan gaya belajar yang berbeda. Perbedaan kemampuan peserta didik disebabkan oleh perbedaan latar belakang mahasiswa. Latar belakang peserta didik yang dapat mempengaruhi kemampuan dalam memahami konsep IPA antara lain adalah asal sekolah, jurusan pada saat sekolah menengah atas (SMA), dan minat terhadap konsep IPA.

Peserta didik yang berasal dari smk dengan jurusan farmasi, perhotelan, atau manajemen membutuhan kerja ekstra untuk memahami konsep IPA SD. Hal ini dikernakan latar belakang pengetahuan yang ditekuni sebelum masuk ke universitas sangat jauh berbeda dengan bidang ilmu yang dipelajari. Hal yang sama juga akan terjadi dengan mahasiswa yang berasal dari jurusan IPS, yang mesti belajar lebih giat untuk memahami konsep IPA yang dipelajari.

Pemahaman siswa terhadap konsep IPA juga dipengaruhi oleh minat mahasiswa belajar IPA. Semakin tinggi minat siswa maka semakin baik pemahaman siswa terhadap materi yang dipelajari (Amalia, 2018; Supardi, Leonard, Suhendri, \& Rismurdiyati, 2012). Oleh karena itu langkah awal dalam pengembangan buku konsep IPA SD adalah mengetahui latar belakang mahasiswa. Berdasarkan keterangan dari bagian input data mahasiswa diperoleh hasil bahwa mahasiswa PGSD berasal dari SMK, MA, SMA IPA, dan SMA IPS. Selain itu, hasil wawancara dengan siswa terhadap alasan mahasiswa memilih PGSD sebagai tempat kuliah adalah keyakinan mahasiswa bahwa pada program studi PGSD materi yang 
Pengembangan Buku Ajar...

diajarkan adalah materi SD sehingga lebih mudah dibandingkan dengan program studi lainnya. Hasil ini menunjukkan bahwa minat siswa terhadap konsep IPA masih rendah.

Latar belakang pendidikan mahasiswa juga mempengaruhi konsepsi peserta didik. Peserta didik dengan latar belakang sekolah kejuruan memiliki prakonsepsi pembelajaran konsep IPA lebih rendah dibandingkan dengan peserta didik yang berasal dari jurusan IPA. Peserta didik yang berasal dari jurusan IPA telah terbiasa dengan fenomena IPA sehingga lebih mudah untuk mempelajari materi IPA lebih tinggi, sedangkan mahasiswa dari SMK memiliki prakonsepsi pembelajaran lebih rendah sehingga perlu kerja ekstra belajar konsep dasar IPA SD untuk memperoleh hasil yang maksimal.

Ada beberapa cara yang dilakukan untuk meningkatkan minat belajar IPA antara lain dengan menggunakan model pembelajaran inovatif, dan modul berbasis masalah (Hadiya, Halim, \& Adlim, 2015; Putrayasa, Syahruddin, \& Mergunayasa, 2014). Dengan demikian upaya meningkatkan minat belajar siswa dapat dilakukan dengan penyajian materi buku ajar yang lebih menarik (Mintowati, 2013).

Bahan ajar yang tersedia berupa buku ajar ditulis berdasarkan pengetahuan dan pendapat penulis tanpa memperhatikan minat, motivasi, dan tingkat kemampuan peserta didik. Akibatnya buku ajar tersebut tidak dapat meningkatkan pemahaman konsep secara maksimal. Bahkan, kadang-kadang buku ajar yang digunakan hanya berupa narasi yang tidak memiliki efek kebermaknaan sehingga mahasiswa hanya disuguhkan materi dalam bentuk hafalan. Penyajian seperti ini menyebabkan peserta didik belajar dengan pasif.

Minat belajar peserta didik terhadap IPA dapat dilihat dari respon siswa terhadap tugas yang diberikan. Tugas pengayaan diberikan untuk meningkatkan pemahaman konsep dan membantu mahasiswa agar pengetahuan dapat terseimpan lebih lama. Akan tetapi, respon siswa terhadap tugas yang diberikan hanya memindahkan penjelasan dari buku ajar ke pembar kerja. Hasil ini menunjukkan bahwa pemahaman siswa terhadap materi yang diberikan masih rendah, karena peserta didik yang memiliki pemahaman konsep yang baik cenderung memberikan jawaban dengan bahasa sendiri dan menurut pemahaman masing-masing.

Respon siswa dengan hanya memindahkan materi dari buku, juga menunjukkan bahwa peserta didik hanya menghapal materi-materi yang disajikan tanpa upaya memahami konsep yang disajikan. Proses pembelajaran seperti ini berdampak pada pengetahuan yang diperoleh tidak dapat bertahan lama sehingga jika dibutuhakan untuk menyelesaikan masalah yang ditemukan pada masa datang tidak dapat digunakan lagi. Dengan demikian dikatakan bahwa pembelajaran kurang bermakna. Oleh karena itu, buku ajar yang digunakan dalam pembelajaran IPA dapat membimbing masiswa melakukan berbagai kegiatan seperti penyelesaian masalah dengan melakukan investigasi kelompok (Santyasa, 2008).

Pembelajaran konsep IPA di program studi PGSD belum memiliki buku acuan baku yang digunakan oleh setiap dosen. Oleh karena itu, masing-masing dosen memiliki persepsi materi apa yang penting diajarkan. Hal ini berdampak pada materi yang diterima siswa akan berbedabeda pula.

Pada program studi PGSD buku ajar yang menjadi rujukan cenderung mengutamakan akselerasi dengan memberikan contoh soal dengan penyelesaian secara matematis dibandingkan dengan penanaman konsep. Akibatnya pengetahuan yang dimiliki peserta didik dari pengalaman belajar sebelumnya seakan-akan terpisah dari pengetahuan yang baru diterima. Tindakan yang dilakukan oleh dosen agar terjadi asimilasi antara pengetahuan lama dan pengetahuan baru untuk membentuk konsepsi peserta didik tidak dapat dilakukkan secara maksimal. Oleh karena pengetahuan baru yang diperoleh peserta didik sebagai hasil proses asimilasi dari pengetahuan awal dan pengalaman baru tidak terwujud pada peserta didik (Kurniahadi, 2008).

Secara umum ada dua faktor yang mempengaruhi konsepsi peserta didik yaitu faktor internal dan faktor eksternal. Buku ajar yang dijadikan sebagai sumber belajar siswa mempengaruhi konsepsi siswa yang merupakan 
Pengembangan Buku Ajar...

salah satu faktor eksternal. Penggunaan bahasa yang sulit dimengerti oleh siswa dapat menjadi penghambat konsepsi siswa bahkan dapat menyebabkan miskonsepsi.

Berdasarkan pada uraian diatas perlu dikembangkan buku ajar konsep IPA yang dapat memenuhi kebutuhan belajar dan karakteristik peserta didik. Karakteristik buku ajar tersebut adalah menyajikan materi dengan berbagai format sehingga dapat membantu semua peserta didik baik klaster rendah, sedang, atau tinggi, bahasa yang digunakan mudah dimengerti dan tidak menimbulkan miskonsepsi, dan melatih keterampilan berpikir peserta didik sehingga materi dapat dIPAhami dengan baik bukan dihafal.

\section{METODE}

Penelitian ini termasuk dalam penelitian pengembangan (development reserach). Model pengembangan yang digunakan adalah model pengembangan modifikasi model evaluasi Tessmer dan model ADDIE. Model pengembangan digunakan untuk memperoleh aspek kevalidan, kepraktisan, dan efek potensial buku ajar.

Subjek dalam penelitian ini adalah mahasiswa Strata-1 semester 1 pada Program Studi PGSD. Penelitian berlokasi di Universitas PGRI Palembang berjumlah 56 orang. Teknik penyampelan yang digunakan adalah purposive sampling.

Instrumen yang digunakan dalam penelitian ini berupa format validasi buku ajar, format praktikalitas, format efektifitas, pedoman wawancara (para ahli, dosen, dan mahasiswa). Seluruh instrumen yang telah dibuat divalidasi oleh pakar, dan teman sejawat. Hasil validasi dan saran ahli merupakan bahan revisi buku ajar yang dikembangkan sehingga menjadi draft buku ajar. Uji validitas meliputi aspek validasi isi dan validasi konstruk, dilakukan oleh pakar dengan teknik pengumpulan data walkthrough. Walkthrough digunakan untuk memperoleh data pendapat ahli mengenai isi, konstruk dan tampilan buku ajar.

Uji praktikalitas dilakukan dengan menggunakan wawancara dan kuesioner/angket untuk melihat bermakna atau tidaknya buku ajar yang dikembangkan. Tidak hanya itu wawancara dan kuesioner, merupakan instrumen untuk memperoleh perbaikan, kritik, dan saran dari peserta didik untuk penyempurnaan pengembangan buku ajar. Uji praktikalitas ini diujikan dalam dua kelompok kecil yaitu one to one evaluation dan small group evaluation. Angket merupakan teknik pengumpulan data yang dilakukan dengan cara memberi seperangkat pertanyaan atau pernyataan tertulis kepada responden untuk dijawabnya (Sugiyono, 2011)

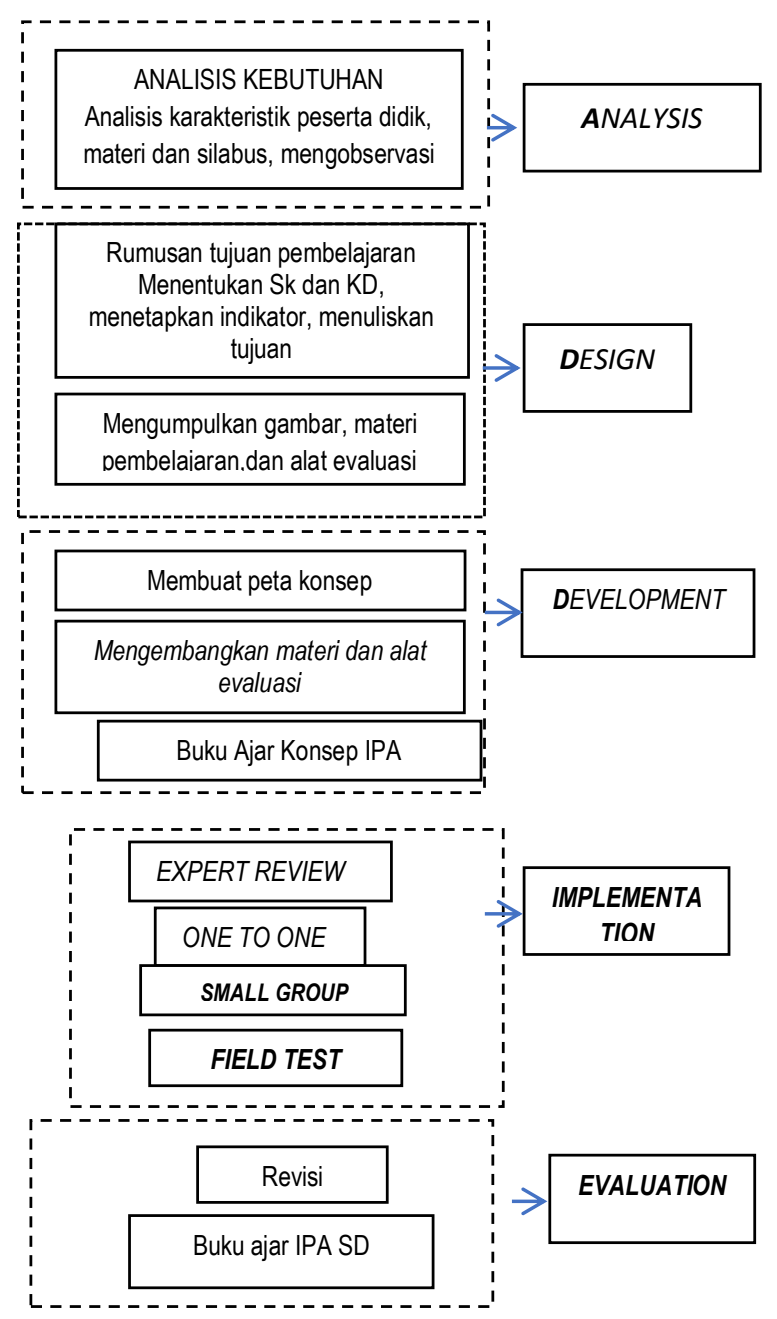

Gambar 1. Diagram alir pengembangan buku ajar Konsep IPA SD

Keefektifan (efek potensial) buku ajar dapat dilihat dari hasil tes pada field test sebagai bagian dari tujuan pembelajaran melalui pretest dan posttest (Suhardjono, 2008). Prosedur penelitian pengembangan ini dapat digambarkan seperti pada gambar 1 .

Berdasarkan gambar 1 diperoleh bahwa 
Pengembangan Buku Ajar...

tahap pengembangan buku ajar meliputi empat (5) tahapan yaitu: tahap analisis, tahap desain, tahap pengembangan, tahap implementasi dan evaluasi.

Tujuan ujicoba one to one pada tiga mahasiswa dalam klaster berbeda untuk melihat pengaruh bukku ajar yang dikembangkan terhadap ketiga kelompok peserta didik tersebut. Jika hasil ujicoba baik maka dapat disimpulkan bahwa buku konsep IPA yang dikembangkan dapat digunakan untuk pembelajaran konsep IPA SD untuk semua klaster peserta didik. Penyampaian materi sesuai dengan tingkat pengetahuan siswa akan memberikan pengaruh yang signifikan pada penguasaan konsep siswa (Hakim, Sinaga, \& Setiawan, 2018).

Untuk mengetahui efektivitas dan kendalakendala yang dialami oleh peserta didik menggunakan buku konsep IPA SD dalam kegiatan pembelajaran maka dilakukukan observasi selama proses pembelajaran. Observasi meliputi respon siswa terhadap buku ajar yang digunakan pada saat diberikan pertanyaan berkenaan konsep-konsep yang sedang dipelajari. Dari hasil pengamatan bahwa sebagian besar siswa berusaha mencari jawaban terhadap pernyataan yang diberikan dari buku ajar yang dikembangkan. Hasil ini menunjukkan bahwa peserta didik memiliki respon yang baik terhadap bukku ajar yang dikembangkan dan memiliki keyakinan terhadap isi buku ajar yang diberikan.

Untuk mengetahui efektivitas buku ajar dalam meningkatkan pemahaman konsep siswa maka dilakukan ujicoba lapangan. Uji coba lapangan menggunakan dua kelas sebagai kelompok kontrol dan kelompok eksperimen.. kelompok kontrol diajarkan dengan menggunakan model pembelajaran langsung dengan menggunakan buku ajar yang biasa digunakan di program studi PGSD sedangkan kelompok eksperimen diajarkan dengan menggunakan pembelajaran langsung dengan menggunakan buku ajar konsep IPA SD yang dikembangkan. Desain penelitian seperti ditunjukkan tabel 1.
Tabel 1. Desain Penelitian

\begin{tabular}{|c|c|c|c|}
\hline Kel & Pretest & Perlakukan & Posttest \\
\hline Eks & $\mathrm{O}_{1}$ & $\begin{array}{c}\text { Buku ajar yang } \\
\text { dikembang }\end{array}$ & $\mathrm{O}_{2}$ \\
\hline Kont & $\mathrm{O}_{1}$ & Buku ajar biasa & $\mathrm{O}_{2}$ \\
\hline
\end{tabular}

Instrumen yang digunakan dalam ujicoba lapangan adalah tes pemahaman konsep berentuk essay dengan jumlah soal sepuluh soal. Materi yang diujikan adalah materi besaran dan satuan. Instrument yang digunakan dalam penelitian ini dinilai oleh ahli dan diujicobakan. Penilaian ahli mencakup kesesuaian antara indicator dengan soal, kesalahan konsep, dan bahasa yang digunakan.

Tanggapan ahli terhadapinstrumen yang dikembangkan adalah semua indicator sesuai dengan soal yang diujikan, tidak ada kesalahan konsep. Penilaian terhadap bahasa yang digunakan, komentar ahli adalah masih ada soal tes yang salah dalam pengetikan atau typo dan penggunaan bahasa yang terlalu banyak sehingga membingungkan peserta didik. Berdasarkan saran dan masukan dari ahli instrument tes diperbaiki dan diujicobakan.

Ujicoba instrument dilakukan pada mahasiswa semester tiga yang telah lulus mata kuliah konsep dasar IPA SD. Hasil ujicoba instrument menunjukkan bahwa realibilitas instrumen 0,72 dengan katagori sangat baik. Hasil ujicoba ini juga dapat diketahui semua soal valid sehingga dapat digunakan dalam penelitian.

Tingkat kesukaran soal terdiri dari soal yang sukar ada 2 soal dan soal yang mudah ada tiga soal. Lima soal lainnya dalam kategori sedang. Untuk daya pembeda dengan katagori baik. Berdasarkan hasil ujicoba ini maka semua soal digunakan dalam tes lapangan.

\section{HASIL DAN PEMBAHASAN}

\section{HASIL}

Hasil penilaian ahli menyatakan bahwa buku ajar sudah valid dan dinyatakan praktis untuk implementasikan. Dengan demikian buku ajar untuk konsep dasar IPA yang dikembangkan dapat diujicobakan pada one to one dan small group dan ujicoba secara luas. Meskipun buku 
Pengembangan Buku Ajar...

ajar yang dikembangkan valid dan pratis akan tetapi para ahli tetap memberikan kritik dan saran untuk perbaikan buku ajar dikembangkan.

Sebelum dilaksanakan ujicoba one to one peserta didik mengikuti proses pembelajaran. Model pembelajaran yang digunakan dalah model pembelajaran langsung. Selama proses pembelajaran peserta didik menggunakan buku ajar konsep dasar IPA SD yang dikembangkan. Setelah mengikuti pembelajaran dengan menggunakan buku ajar konsep IPA SD yang dikembangkan peserta didik ditanya tentang tanggapannya terhadap buku ajar yang digunakan. Berdasarkan hasil wawancara dengan peserta didik maka dapat diketahui bahwa peserta didik memiliki tanggapan yang positif terhadap buku ajar konsep yang dikembangkan (Rasyid, 2018; Utami, R. Sumarni, W. Habibah, 2017). Hasil ini menunjukkan bahwa buku ajar konsep dasar IPA SD yang dikembangkan dapat digunakan sebagai buku teks dalam pembelajaran konsep IPA SD dan dapat meningkatkan minat peserta didik untuk belajar konsep IPA SD (Riwahyudin, 2015).

Ujicoba one to one buku ajar yang dikembangkan menggunakan konstruksi pendekatan 5E (Kurnaz \& Çalik, 2008). Ujicoba one to one dilakukan pada tiga mahasiswa yang sedang mengambil mata kuliah konsep Dasar IPA SD. Ketiga peserta didik tersebut mewakili kelompok yang memiliki kategori berkemampuan rendah, berkemampuan sedang, dan berkemampuan tinggi.

Pada Ujicoba one to one penerapan buku ajar konsep dasar IPA SD. Berdasarkan hasil ujicoba one to one dapat diketahui kesulitan peserta didik dalam memahami macam-macam besaran turunan dan dimensi besaran, peserta didik belum mengerti simbol-simbol fungsi yang digunakan pada buku ajar yang dikembangkan. Dengan demikian sebagai masukan untuk revisi buku ajar konsep IPA SD adalah penjelasan penjelasan terhadap konsep dasar IPA SD lebih cenderung untuk membahas tentang konsep IPA dan penerapan konsep IPA tersebut dalam kehidupan sehari-hari. Untuk meningkatkan pemahaman peserta didik terhadap simbolsimbol fungsi yang digunakan pada buku ajar adalah dengan membiasakan peserta didik menggunakan simbol-simbol yang baku dalam kegiatan penyelesaian masalah.

Sebagai alternatif pemecahan masalah maka peserta didik harus memahami simbolsimbol yang digunakan dalam buku ajar. Oleh karena itu temuan ini menjadi bukti bahwa pembelajaran konsep dasar IPA SD tidak bisa memberikan hasil maksimal jika hanya menekan pada hapalan siswa terhadap konsepkonsep yang diberikan. Tabel 2. Menunjukkan komentar dan saran mahasiswa pada tahap ujicoba one to one

Tabel 2. Komentar dan saran mahasiswa pada tahap one to one

\begin{tabular}{|c|c|c|}
\hline Mhs & Komentar & $\begin{array}{c}\text { Tanggapan } \\
\text { Peneliti }\end{array}$ \\
\hline M1 & $\begin{array}{l}\text { a. Belum terdapat } \\
\text { gambar yang jelas. } \\
\text { b. Dibuat kolom isian } \\
\text { untuk menjawab } \\
\text { soal-soal }\end{array}$ & $\begin{array}{l}\text { Akan diperjelas } \\
\text { gambar } \\
\text { Akan dibuat } \\
\text { kolom isian. }\end{array}$ \\
\hline M2 & $\begin{array}{l}\text { a. Penjelasan buku ajar } \\
\text { sudah lengkap dan } \\
\text { diperbanyak lagi } \\
\text { contoh soal sehingga } \\
\text { saya paham buku } \\
\text { ajar konsep Dasar } \\
\text { IPA. } \\
\text { b. Menurut saya buku } \\
\text { ajar ini materinya } \\
\text { lengkap, sistematis, } \\
\text { teratur dan sangat } \\
\text { membantu saya } \\
\text { dalam mempelajari } \\
\text { konsep Dasar IPA. }\end{array}$ & $\begin{array}{l}\text { Akan } \\
\text { diperbanyak } \\
\text { contoh soal dan } \\
\text { latihan. }\end{array}$ \\
\hline M3 & $\begin{array}{l}\text { a. Buatkan tips langkah } \\
\text { langkah pengerjaan } \\
\text { soal. } \\
\text { b. Contoh soal yang } \\
\text { menyangkut materi } \\
\text { sangat sedikit. }\end{array}$ & $\begin{array}{l}\text { Akan } \\
\text { diperbanyak } \\
\text { contoh soal dan } \\
\text { latihan. }\end{array}$ \\
\hline
\end{tabular}

Berdasarkan Tabel 2 dapat diketahui bahwa peserta didik dalam pembelajaran konsep IPA SD membutuhkan banyak contoh soal dan pembahasan. Tanggan ini diberikan oleh peserta didik klaster sedang dan klaster tinggi. Soal latihan dan pembahasan ini merupakan sarana bagi peserta didik untuk belajar dan melatih keyakinan peserta didik terahadap hasil penyelesaian masalah yang diberikan. Semakin banyak peserta didik menjawab persoalan yang diberikan dengan benar maka semakin tinggi tingkat kepercayaan peserta didik terhadap penyelesaian masalah yang diberikan.

Pada peserta didik kelompok rendah membutuhkan gambar yang jelas. Gambar yang 
Pengembangan Buku Ajar...

digunakan untuk mengilustrasikan konsep atau fenomena membantu peserta didik dalam memahami kosep-konsep IPA yang disajikan. Gambar memberikan seribu penjelasan dan dapat membantu mengungkapkan konsepkonsep abstrak menjadi lebih konkret. Dengan demikian hasil penelitian ini menunjukkan bahwa menggunakan gambar dalam menjelsakan konsep IPA bagi peserta didik dalam klaster rendah menjadi sangat esensial dalam upaya membantu peserta didikan memahami konsep yang diberikan.

Tabel 3. Rekapitulasi Hasil Angket pada Tahap Small Group

\begin{tabular}{|c|c|c|c|}
\hline No & Pernyataan & Rerata & Ket \\
\hline 1 & $\begin{array}{l}\text { Minat siswa terhadap } \\
\text { buku ajar }\end{array}$ & 4,75 & Baik \\
\hline 2 & $\begin{array}{l}\text { Membantu siswa } \\
\text { memahami materi yang } \\
\text { dipelajari }\end{array}$ & 4,50 & Baik \\
\hline 3 & $\begin{array}{lr}\text { Bahasa yang } \\
\text { digunakan jelas } & \text { dan } \\
\text { mudah dIPAhami } & \end{array}$ & 4,63 & Baik \\
\hline 4 & $\begin{array}{l}\text { Kepaduan antara teks, } \\
\text { gambar, dan grafik }\end{array}$ & 4,63 & Baik \\
\hline 5 & $\begin{array}{l}\text { Meningkatkan motivasi } \\
\text { belajar }\end{array}$ & 4,63 & Baik \\
\hline
\end{tabular}

Berdasarkan Tabel 3 diperoleh rata-rata hasil angket atau kuesioner peserta didik terhadap penggunaan buku ajar konsep dasar IPA 4,63 dengan skor maksimal 5 atau 92 dengan skor maksimum 100. Berdasarkan tanggapan peserta didik tersebut dikatakan bahwa peserta didik memberikan tanggapan yang sangat baik terhadap buku ajar konsep IPA yang dikembangkan. Dengan demikian buku ajar yang dikembangkan dengan katagori baik dan praktis sehingga dapat digunakan untuk pembelajaran konsep dasar IPA SD secara luas. Hasil ini juga menunjukkan bahwa keterbacaan buku ajar konsep IPA SD sudah baik karena tidak mengandung kalimat ambigu dan menggunakan bahasa Indonesia yang baik dan benar.

\section{Hasil Uji lapangan}

Ujicoba field test atau uji lapangan bertujuan untuk menguji efek potensial pemahaman konsep siswa dengan menggunakan buku ajar yang dikembangkan. Data hasil ujicoba lapangan berupa hasil pretest sebelum pembelajaran menggunakan buku yang dikembangkan dan posttest sesudah pembelajaran.

Hasil pretest dan posttest seperti ditunjukkan pada gambar 2 .

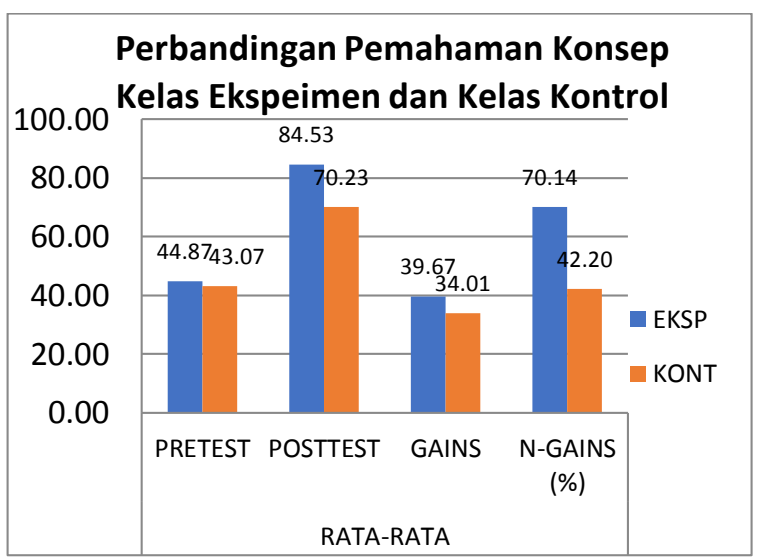

Gambar 2. Grafik Perbandingan Pemahaman Konsep Kelas Eksperimen dan Kelas Kontrol

Hasil pretest dan posttest kelas eksperimen adalah 44,87 dan 84,53 sedangkan untuk kelas kontrol 43,07 dan 70,23. Rata-rata $\mathrm{N}$-gain kelas eksperimen adalah 0,70 dengan katagori tinggi sedangkan untuk kelas kontrol rata-rata $\mathrm{N}$-gains adalah 0,42. Berdasarkan hasil ini dapat diketahui bahwa pemahaman konsep peserta didik pada kelas eksperimen yang menggunakan buku ajar yang dikembangkan lebih tinggi dibandingkan dengan pemahaman konsep peserta didik pada kelas kontrol. Untuk melihat apakah terdapat perbedaan signifikan antara pemahaman konsep kelas eksperimen dengan kelas kontrol maka dilakukan uji hipotesis perbedaan dua rata-rata. Uji hipotesis menggunakan uji-t. Akan tetapi sebelum dilakukan uji $\mathrm{t}$ terlebih dulu dilakukan uji prasyarat yaitu uji normalitas dan uji homogenitas.

Hasil uji normalitas diperoleh hasil 0,35 sehingga data terdistribusi normal. Hasil uji homogenitas dengan menggunakan uji lavine diperoleh hasil 0,5 yang menunjukkan bahwa data homogen. Data normal dan homogen sehingga uji t dapat dilakukan. Hasil uji t dengan menggunakan $\alpha=0,05$. Hasil pengujian dengan bantuan SPSS menunjukkan bahwa signifikan dalah 0.00. Dari hasil uji $t$ dapat disimpulkan 
Pengembangan Buku Ajar...

bahwa penerapan buku ajar secara signifikan dapat meningkatkan pemahaman konsep siswa

\section{PEMBAHASAN}

Tanggapan peserta didik terhadap buku ajar konsep dasar IPA positif. Peserta didik dari klaster rendah menginginkan agar gambar yang ditampilkan lebih jelas dan lebih detil. Gambar yang terdapat pada buku ajar konsep IPA mencakup gambar alat ukur seperti jangka sorong, mikrometer sekrup, dan neraca. Penyajian gambar yang lebih jelas akan memberikan kemudahan peserta didik untuk membaca angka yang ditunjukkan oleh alat ukur yang digunakan.

Peserta didik pada klaster rendah memiliki tingkat keyakinannya terhadap penyelesaian soal dalam katagori rendah. Jika alat ukur menunjukkan angka yang susah dibaca maka memberikan keraguan pada peserta didik terhadap hasil yang diperoleh dan dapat menyebabkan minat peserta didik belajar jadi berkurang. Oleh karena itu, untuk menjaga minat peserta didik belajar maka gambar yang disajikan jelas dan menarik.

Pada peserta didik kelompok rendah juga menginginkan agar penyelesaian masalah yang diberikan runut dan lengkap. Tujuan penulisan penyelesaian masalah runut dan lengkap adalah agar peserta didik kelompok rendah dapat mengikuti setiap langkah yang diberikan tanpa harus mencari pada sumber yang lain. Pennyelesaian masalah yang kurang lengkap mengharuskan peserta didik untuk memahami beberapa langkah yang hilang sampai ditemukan langkah berikutnya. Hal ini menjadi wajar karena peserta didik pada klaster rendah masih perlu bimbingan untuk menyelesaiakan masalah. Hal ini juga terjadi pada saat proses pembelajaran, peserta didik pada klaster rendah cenderung pasif dan menunggu instruksi untuk menulis langkah-langkah penyelesaian masalah yang diberikan.

Pada klaster sedang dan tinggi, peserta didik telah memiliki keyakinan terhadap hasil penyelesaian masalah yang diberikan. Oleh karena itu peserta didik membutuhkan soal-soal latihan sebagai pengayaan terhadap materi yang dipelajari. Peserta didik pada klaster ini juga memiliki kemandirian dalam menyelesaikan masalah sehingga penyelesaian masalah yang diperoleh tidak harus dikonfirmasi lagi ke dosen pengampuh mata kuliah. Hasil ini mendukung pendapat bahwa peserta didik pada klaster sedang dan tinggi memiliki kemandirian belajar sehingga salah satu upaya untuk meningkatkan pemahaman konsep melalui latihan penyelesaian masalah mandiri.

Revisi dari hasil ujicoba one to one dengan memperhatikan masukan dari peserta didik sebagai pengguna. Selanjutnya ujicoba dengan skala kecil. Revisi pada tahap ujicoba telah cukup memenuhi kebutuhan peserta didik dari berbagai klaster. Hal ini ditunjukkan dari tanggapan peserta didik terhadap buku ajar yang digunakan. Buku ajar yang digunakan dapat meningkatkan minat peserta didik belajar konsep IPA. Peningkatan minat belajar peserta didik dikarena kepaduan gambar dan teks sehingga yang saling melengkapi. Selain itu, bahasa yang digunakan mudah jelas dan mudah dimengerti.

Untuk menguji keefektifan buku ajar dalam meningkatkan pemahaman konsep peserta didik terhadap konsep IPA maka dilakukan ujicoba skala luas. Hasil ujicoba skala luas menunjukkan bahwa terdapat perbedaan signifikan pemahaman konsep antara kelompok eksperimen dengan kelompok kontrol. Hasil ini menunjukkan bahwa buku ajar yang digunakan lebih dapat meningkatkan pemahaman konsep siswa dibandingkan dengan buku ajar biasa.

Berdasarkan hasil penelitian ini maka dapat diketahui penerapan multirepresentasi dalam buku ajar membantu siswa memahami konsep dasar IPA. Pemahaman konsep yang dikembangkan adalah kemampuan mengubah bentuk representasi menjadi representasi yang lain, kemampuan ekstrapolasi dan intrapolasi grafik dari persamaan matematik, kemampuan menginterpretasi grafik.

Kemampuan ini sangat bermanfaat bagi peserta didik untuk mengembangkan diri dan karir masa depan. Kemampuan memanfaatkan peluang yang ada menjadikan peserta didik lebih kuat dan tanggu sehingga menjadikan mereka lebih lebih siap menghadapi berbagai tantangan yang dihadapi dalam kehidupan masyarakat. Karena pemahaman terhadapa konsep dasar IPA merupakan sarana untuk 
Pengembangan Buku Ajar...

berlatih kemampuan berpikir dan menerapkan hasil pemikiran tersebut guna menyelesaiakan setiap masalah yang dihadapi. Dengan demikian pembelajaran IPA adalah sarana untuk mempersiapkan peserta didik dalam menghadapi setiap perubahan yang terjadi.

$\begin{array}{ccc}\text { Buku ajar } & \text { yang } & \text { dikembangkan } \\ \text { menggunakan } & \text { pendekatan } & 5 \mathrm{E} \text { yakni } \\ \text { engagement } & \text { (keterlibatan), } & \text { exploration } \\ \text { (penjajakan), } & \text { explanation } & \text { (penjelasan), }\end{array}$
elaboration (penguraian), dan evaluation (evaluasi) yang memiliki kelebihan dan kekurangan yang bertujuan untuk meningkatkan peran aktif peserta didik dalam belajar. Penerapan pendekatan 5E pada buku ajar konsep dasar IPA yang telah dikembangkan memberikan keuntungan antara lain membantu peserta didik belajar mengalami dengan urutan yang sesuai dalam menghubungkan pengetahuan awal dengan konsep baru;

Peserta didik terlibat dalam pembentukan konsep baru melalui pertanyaan yang diberikan. Pertanyaan tersebut merangsang peserta didik menerapkan pengetahuan yang telah dimiliki untuk berasimilasi dengan pengalaman baru sehingga membentuk pengetahuan baru. Konflik kognitif dirancang agar peserta didik mencapai mencapai konsep yang lebih tinggi dengan meningkatkan keingintahuan terhadap fenomena-fenomena yang baru. Pertanyaan awal diperkirakan membuat sebuah hubungan antara pengetahuan awal dan pengalaman belajar baru sebagai hasil belajar.

Eksplorasi; melalui kegiatan diskusi untuk mengekploitasi pengetahuan awal peserta didik agar menghasilkan ide-ide baru yang bersifat tentatif. Penjelasan; memberi kesempatan peserta didik mengungkapkan pengetahuan yang diperoleh selama belajar sehingga tersimpan lebih lama dalam memori. Elaborasi; untuk memperluas pengetahuan terstruktur baru peserta didik, mempertahankan dan memperluas pemahaman terhadapa pengetahuan yang diperoleh. Evaluasi; fase memberikan kesempatan peserta didik mengakses pemahaman dan kemampuan yang diperoleh selama pembelajaran seberapa besar materi atau konsep yang diberikan terserap oleh peserta didik.

\section{PENUTUP}

Hasil penelitian ini memberikan kesimpulan sebagai berikut:

Buku ajar konsep dasar IPA yang dikembangkan memiliki kategori baik secara isi, dan konstruk oleh ahli materi dan ahli desain pembelajaran sehingga layak digunakan dan layak digunakan.

Penggunaan buku ajar konsep dasar IPA yang dikembangkan secara signifikan dapat meningkatkan pemahaman konsep siswa.

\section{UCAPAN TERIMA KASIH}

Penelitian ini didanai oleh LPPKM Universitas PGRI Palembang. Oleh karena itu, kami ucapkan terima kasih atas kesempatan dalam kegiatan penelitian ini.

\section{DAFTAR PUSTAKA}

Doyan, A., Taufik, M., \& Anjani, R. (2018). Pengaruh Pendekatan Multi Representasi Terhadap Hasil Belajar Fisika Ditinjau Dari Motivasi Belajar Peserta Didik. Jurnal Penelitian Pendidikan IPA, 4(1). https://doi.org/10.29303/jppIPA.v4i1.99

Hadiya, I., Halim, A., \& Adlim. (2015). Pengembangan Modul Pembelajaran Suhu Dan Kalor Berbasis Masalah Untuk Sma Dalam Upaya Meningkatkan Minat Belajar Siswa. Jurnal Pendidikan Sains Indonesia, 03(1), 81-92.

Hakim, L., Sinaga, P., \& Setiawan, A. (2018). Pengembangan Konten Materi Listrik Magnet Adaptif Untuk Calon Guru. WaPFi (Wahana Pendidikan Fisika). https://doi.org/10.17509/wapfi.v3i1.10987

Kurnaz, M. A., \& Çalik, M. (2008). Using different conceptual change methods embedded within the 5E Model: A sample teaching for heat and temperature. Physics, 5(1).

Kurniahadi, K. (2008). Pengaruh Metode Perubahan Konseptual dalam Setting Model 5E Terhadap Pemahaman Konsep Siswa SMA Lab. Undiksha Singaraja: Undiksha.

Lefudin. (2018). Pengembangan Buku Ajar Untuk Mata Kuliah Mekanika Lanjutan Di Program Studi Pendidikan Fisika Fakultas Keguruan Dan IImu Pendidikan 
Pengembangan Buku Ajar...

Universitas. JURNAL INOVASI DAN PEMBELAJARAN FISIKA, 5(1).

Mintowati. (2013). Panduan Penulisan Buku Ajar. Jakarta: Depdikbud.

Putrayasa, I. M., Syahruddin, H., \& Mergunayasa, I. G. (2014). Pengaruh Model Pembelajaran Discovery Learning Dan Minat Belajar Terhadap Hasil Belajar IPA Siswa. Jurnal Mimbar PGSD Universitas Pendidikan Ganesha, 2(1), 111. https://doi.org/10.1093/brain/awt103

Rasyid, A. (2018). Pengembangan Media Pembelajaran IPA Bervisi Sets Berbasis Edutainment Pada Konsep Pencernaan. Jurnal Bio Educatio, 3(1), 53-59. https://doi.org/10.1017/CBO97811074153 24.004

Riwahyudin, A. (2015). Pengaruh Sikap Siswa Dan Minat Belajar Siswa Terhadap Hasil Belajar IPA Siswa Kelas V Sekolah Dasar Di Kabupaten Lamandau. JURNAL PENDIDIKAN DASAR, 6(1), 10-23. https://doi.org/10.1017/CBO97811074153 24.004

Amalia, R. dan I. Y. (2018). Penerapan Pendekatan Problem Posing Untuk Meningkatkan Kemampuan Representasi Visual Matematis Siswa SMP. Seminar Nasional Pendidikan Fisika 2018. 3(2), 227-234.

Santyasa, I. W. (2008). Pengembangan pemahaman konsep dan kemampuan pemecahan masalah fisika bagi siswa sma dengan pemberdayaan model perubahan konseptual berseting investigasi kelompok. Universitas Pendidikan Ganesha.

Setyandaru, T. A., Wahyuni, S., \& Pramudya, D. (2017). Pengembangan Modul Pembelajaran Berbasis Multirepresentasi pada Pembelajaran Fisika di SMA/MA. Jurnal Pembelajaran Fisika, 6(3), 218224.

Suastra, I. W. (2004). Belajar dan Pembelajaran Sains. Buku Ajar. Singaraja: IKIP Singaraja.

Sugiyono. (2011). Metode Penelitian Pendidikan: Pendekatan Kuantitatif, Kualitatif, dan $R \& D$. Bandung: Alfabeta.

Suhandi, A., \& Wibowo, F. C. (2012). Pendekatan Multirepresentasi Dalam Pembelajaran Usaha-Energi Dan Dampak Terhadap Pemahaman Konsep Mahasiswa. Jurnal Pendidikan Fisika Indonesia, $\quad 8(1), \quad 1-7$. https://doi.org/10.15294/jpfi.v8i1.1988

Suhardjono. (2008). Menyusun Bahan Ajar Agar Tujuan Perkuliahan Tercapai Lebih Menyenangkan. Malang: Jurusan Sipil Fakultas Teknik Universitas Brawijaya.

Supardi, S. U. S., Leonard, L., Suhendri, H., \& Rismurdiyati, R. (2012). Pengaruh Media Pembelajaran dan Minat Belajar Terhadap Hasil Belajar Fisika. Formatif: Jurnal IImiah Pendidikan MIPA, 2(1), 71-81. https://doi.org/10.30998/formatif.v2i1.86

Utami, R. Sumarni, W. Habibah, N. A. (2017). Pengembangan Bahan Ajar IPA Terpadu Berbasis Salingtemas Pada Tema Energi. Unnes Science Education Journal, 6(1), 1496-1502.

https://doi.org/http://dx.doi.org/10.15294/us ej.v3i2.3349 